\title{
Opiate Antagonist
}

National Cancer Institute

\section{Source}

National Cancer Institute. Opiate Antagonist. NCI Thesaurus. Code C681.

Any agent that binds to or interferes with binding to any of the opioid receptor subtypes,

thereby blocking the actions of opioid agonists. 